\title{
The Use of Minimal Invasive Surgery versus Open Approach in Hospitalized Cases
}

\section{A Study Analysis of the DRG Romanian Database 2008-2018}

\author{
Cristian Vladescu ${ }^{1,2 *}$, Catalin Copaescu $u^{3,4}$ \\ 'Faculty of Medicine, University Titu Maiorescu, Bucharest \\ ${ }^{2}$ National School of Public Health Management and Professional Development, Bucharest, Romania \\ ${ }^{3}$ Ponderas Academic Hospital, Bucharest Romania \\ 4"GT Popa" University of Medicine and Pharmacy, Iasi, Romania
}

*Corresponding author:

Cristian Vladescu, MD, PhD

Professor of Public Health

Faculty of Medicine

University Titu Maiorescu, Bucharest

National School of Public Health

Management and Professional

Development, Bucharest

Vaselor Street 32, Romania

E-mail: cristian.vladescu@gmail.com

\section{Rezumat}

Utilizarea chirurgiei minim invazive versus abordarea deschisă în cazurile spitalizate. $O$ analiză a datelor din baza DRG România, 2008-2018

Introducere: Progresul în dezvoltarea şi utilizarea chirurgiei minime invazive (MIS) solicită decizii clinice şi manageriale care trebuie să fie bazate pe dovezi; actualmente lipsesc evidențele ştiințifice privind practica medicală românească. Studiul nostru îşi propune să analizeze utilizarea MIS şi a chirurgiei deschise în România şi impactul tipului de tehnica operatorie asupra spitalizării.

Metodologie:Studiu transversal privind activitatea spitalelor care raportează date primare DRG la nivel de pacient, în perioada 20082018; toate episoadele cu intervenții chirurgicale care ar putea fi efectuate prin MIS sau printr-o abordare chirugicală deschisă au fost extrase din baza de date DRG National; a fost realizată o analiză comparativă a volumului de activitate şi a consecintelor asupra duratei medii de spitalizare (DMS) şi în termeni economici. Rezultate: Modelul de utilizare pentru intervențiile MIS şi interventiile chirurgicale deschise s-a schimbat în perioada 20082018; MIS s-au dublat în timp ce interventiile clasice nu au urmat aceeaşi rată de creştere; DMS pentru MIS scade anual într-un ritm mai alert decât scăderea DMS pentru interventiile chirurgicale deschise; în privința DMS, decalajul dintre cele două a crescut treptat în favoarea MIS. Cea mai evidentă scurtare a DMS pentru MIS a fost găsită pentru afecțiuni ale vezicii biliare (cu 7,95 zile), 
stomacului (cu 5,64 zile) şi pentru eventrații (cu 4,33 zile). Nivelul de rambursare pentru intervențiile MIS versus intervenții chirurgicale deschise nu s-a modificat în perioada analizată.

Concluzii: MIS reduce semnificativ DMS în România, cu o potențială influență pozitivă asupra bugetului național de asistență medicală. Cu toate acestea, modelul de utilizare pentru intervențiile MIS nu se bazează pe stimulente financiare şi necesită de urgență o analiză aprofundată a altor factori care aparțin mai degrabă patologiei specifice, tehnologiei sau practicii medicale (experiență în utilizarea laparoscopiei, dotare, siguranță, eficacitate, zona de abord chirurgical etc.).

Cuvinte cheie: chirurgie minim invazivă (MIS), laparoscopie, intervenție chirugicală deschisă, DMS România

\begin{abstract}
Background: The progress in development and application of Minimal Invasive Surgery (MIS) requires clinical and managerial decisions that must be evidence based; the current available scientific evidence for the Romanian medical practice is missing. Our study aims to analyze the use of MIS and open surgery in Romania and the impact of the type of surgery on the hospitalization. Methodology: A cross-sectional study analyzed the activity of the Romanian hospitals reporting primary Diagnostic Related Group (DRG) data at the patient level in the period 2008-2018; all episodes of abdominal and thoracic surgical interventions which may be performed either by MIS or an open approach were extracted from the DRG National database (www.drg.ro). A comparative analysis in terms of the volume of activity and their impact on the hospital average length of stay (ALOS) has been performed.

Results: The pattern of use for MIS and open surgery interventions was changed in 2008-2018; MIS procedures doubled while open surgery interventions did not follow the same growth rate; ALOS for the MIS procedures decreased annually at a faster rate as compared to the ALOS for the open surgery and the gap between the two gradually increased in favour of the MIS interventions. The most pronounced shortening of ALOS after MIS procedures has been found for Gallbladder Surgery (by 7.95 days), Gastric Surgery (by 5.64 days) and Incisional Hernia surgery (by 4.33 days). Meanwhile, the reimbursement level for the MIS versus open surgery interventions did not changed over the analyzed period.

Conclusions: MIS is significantly reducing the ALOS in Romania with a potential positive influence on the national healthcare budget. However, the pattern of use for MIS interventions is not financial incentives based and calls for in-depth analysis on other factors belonging rather to specific pathology, technology or medical practice (experience in using MIS, endowment, safety, efficacy, surgical approach area etc.) is urgently required.
\end{abstract}

Key words: MIS, laparoscopy, open surgery interventions, surgical, Romania

\section{Introduction}

As great progress was recently encountered in the medical field, the surgery was the beneficiary of many applications and technologies that, over time, proved their effectiveness and efficiency in solving surgical cases. Initially appearing to improve the diagnosis in surgical cases (in the 1960s)(1), laparoscopy has been developed as an operative technique in the '80s and '90s, later become gold standard therapy for many surgical pathologies (after 
2000), naming among the most commonly used, gynecology and digestive surgery (i.e. cholecystectomy)(2). Significant improvements in surgical training, as well as developments of instruments, equipment, imaging and surgical techniques, have greatly increased safety and feasibility of the laparoscopic surgical procedures (3). As laparoscopic surgery became a better option for the most abdominal operations, the application of the videoassisted techniques has been extended to other anatomical areas, generating new approaches, for example: thoracoscopy for chest pathology, arthroscopy for joints etc. All these new techniques were grouped in the progressive domain of Minimal Invasive Surgery (MIS) (4). The notable benefits of MIS to patients include less postoperative pain, fewer operative and post-operative major complications, shortened hospital stay, faster recovery times, less scarring, less stress on the immune system, smaller incision, and for some procedures reduced operating time and reduced costs (5). Under these circumstances, MIS procedures are expected to become standard of care for many pathologies, as the experience of the medical teams, but also the technological improvements will universally reach an acceptable level of safety, efficacy, and effectiveness for the specific approach.

The introduction of MIS in Romania was enthusiastically supported by various hospitals in the '90s (6).

but the low public investment in the specific technology (equipment, instruments and training) limited its wide application in the Romanian hospitals. The Romanian Association for Endoscopic Surgery (ARCE) noticed the reduced use of these techniques in our country and, in 2006, it runs a nationalwide investigational study to explore the status of laparoscopic surgery in Romania (7). The results of this study argued for the National Program for Developing Laparoscopic Surgery in Romania, run and supported by the Romanian Minister of Heath, between 2007 and $2010(7,8)$.

In the same decade, Romania started using the Diagnostic Related Group (DRG) mecha- nism, by introducing the US DRG in 2003 and switching from the US version to the Australian one in 2007 and starting with 2011 the Romanian version - Ro DRG (9). Therefore, since then all the national data analyzed by the National School of Public Health, Management and Professional Development in Health Bucharest (NSPHMPDHB) have structural validity (same DRG system and the same ICD 10 used for reporting)(10).

However, despites the above-mentioned institutional progress, aside from the scientific publications of technical aspects and small cohort's outcomes of laparoscopic surgery (6), large studies on the MIS impact on the health care system in Romania are missing or scarce.

We consider that providing available scientific evidence on medical practice regarding the use of MIS in Romania is mandatory to support the decision-making process.

The present study aims to analyze the use of minimal invasive surgery (MIS) and open surgery in Romania and the type of surgery impact on the hospitalization ten years after a significant investment in MIS.

\section{Methodology}

A cross-sectional study analyzed the activity of the Romanian hospitals reporting primary DRG data at the patient level, in the period 2008-2018-time interval. The data on hospitalization episodes for the patients who underwent MIS and open surgery interventions in this time-interval was extracted from the DRG National Database recorded at NSPHMPDHB. In this study were included only episodes with surgical interventions that could be performed either by MIS (laparoscopic or thoracoscopic) or open surgery. These data included all episodes having a dedicated code for MIS procedure (Table 1A) and the episodes coded as surgical procedures to which laparoscopy is added (J12001), to mark that it was performed by MIS (Table 1B). Data were aggregated and analyzed to the hospital episodes level. We examined and compared aggregate time trends of the number of episodes and proportion of patients undergoing 
Table 1A. List of dedicated codes for MIS - minimal invasive surgery (thoracic and abdominal surgical procedures with laparoscopy)

\begin{tabular}{ll}
\hline $\begin{array}{l}\text { Investigated Surgical } \\
\text { Area or Organ }\end{array}$ & $\begin{array}{l}\text { Codes of the investigated MIS } \\
\text { procedures }\end{array}$ \\
\hline Thoracic Procedures & G03003, G04001, G04002, G04003, H04601 \\
\hline GYN & I01101, I01103, I01105, \\
\hline Spleen & I01603 \\
\hline GERD & J03601, J03602 \\
\hline Appendix & J07002 \\
\hline Gallbladder & J10102, J10103, J10104, J10105 \\
\hline Hernia & $\mathrm{J} 12601, \mathrm{~J} 12602, \mathrm{~J} 12701, \mathrm{~J} 12702$ \\
\hline GYN & $\mathrm{M} 00201, \mathrm{M} 00501, \mathrm{M} 00502, \mathrm{M} 01001$, \\
& $\mathrm{M} 01002, \mathrm{M} 01201, \mathrm{M} 012023, \mathrm{M} 01204$, \\
& $\mathrm{M} 01301, \mathrm{M} 01302, \mathrm{M} 01303, \mathrm{M} 02703$, \\
& $\mathrm{M} 03007, \mathrm{M} 03008, \mathrm{M} 03010, \mathrm{M} 03011$, \\
\hline Exploratory Laparoscopy & $\mathrm{J} 03204, \mathrm{M} 03301, \mathrm{M} 06002$ \\
\hline
\end{tabular}

surgery on the two types of techniques: MIS and open surgery interventions.

Hospital average length of stay (ALOS) by type of interventions and pathology were analyzed in order to identify the patterns of surgical technique use.

The reimbursement level for an episode of MIS and open surgery intervention respectively, was estimated in RON (Romanian currency) by values of TCP (tariff per weighted case) for the studied period.

\section{Statistical Analysis}

Data were analysed statistically by using uni- and bivariate analysis for the two types of surgery procedures (the absolute and relative frequencies are presented in the results section). Pearson correlation coefficient $(95 \%$ confidence interval, $\mathrm{p}<0.05)$ was calculated for verifying the correlation between the quantitative parameters of the two types of analysed surgery interventions. T-test was used to compare the mean values for MIS and open surgery data. A linear regression analysis was performed for identifying the linear trend in number of MIS, respectively number of open surgery interventions, where the time units (as independent variable) was represented by the variable "year".
Table 1B. List of surgical procedures to which laparoscopy (code J12001) may be added when performed laparoscopically

\begin{tabular}{|c|c|}
\hline $\begin{array}{l}\text { Investigated Surgical } \\
\text { Area or Organ }\end{array}$ & $\begin{array}{l}\text { Codes of the investigated surgical } \\
\text { procedures }\end{array}$ \\
\hline $\begin{array}{l}\text { Surgery in Thorax and } \\
\text { Mediastinum }\end{array}$ & $\begin{array}{l}\text { B02001, G02802, G03001, G03001, G03004, } \\
\text { G03103, G03104, G03202, G03203, G03204, } \\
\text { G03205, G03301, G03302, G03401, G03403, } \\
\text { G03501, G03502, G03503, G03701, G03702, } \\
\text { G03703, G03901, G04801, G04802, G04803, } \\
\text { H04404, S06805, I00601 }\end{array}$ \\
\hline Spleen Surgery & I01601, I01602, I01701 \\
\hline Gastric Surgery & $\begin{array}{l}\text { J02201, J02601, J02602, J02603, } \\
\text { J02701, J02702, J02703, J02801, } \\
\text { J02802, J03001, J03002, J03003, } \\
\text { J03103, J03201, J03202, J03704 }\end{array}$ \\
\hline $\begin{array}{l}\text { Obesity Surgery } \\
\text { Procedures }\end{array}$ & $\begin{array}{l}\text { J03902, J03903, J03904, J03905, } \\
\text { J04001 }\end{array}$ \\
\hline Small Bowel Interventions & $\begin{array}{l}\text { J04501, J04502, J04601, J04604, } \\
\text { J04801, J04802, J04902, J04903, } \\
\text { J05001, J05002, J05101, J05106, } \\
\text { J05301 }\end{array}$ \\
\hline Colorectal Procedures & $\begin{array}{l}\text { J06201, J06202, J06203, J06205, J06210, } \\
\text { J06302, J06402, J06403, J06501, J06502, } \\
\text { J06606, J06607, J06609, J06610, J06801, } \\
\text { J06802, J06803, J06804, J06902, J07001, }\end{array}$ \\
\hline Appendicectomy & J07001 \\
\hline Rectal Surgery & $\begin{array}{l}\text { J07701, J07703, J07710, J07801, J07805, } \\
\text { J07806, J07901, J07902, J07903, J07904, } \\
\text { J08401, J08601 }\end{array}$ \\
\hline Hepato-biliary Procedures & $\begin{array}{l}\text { J08904, J08905, J08906, J08907, J08908, } \\
\text { J09003, J09004, J09103, J09203, J10106, } \\
\text { J10107, J10202, J10203, J10509 }\end{array}$ \\
\hline Hernia Procedures & $\begin{array}{l}\text { J12603, J12604, J12703, J12704, J12801, } \\
\text { J12802, J12803, J12901, J12902, J12903, } \\
\text { J12904, J13001, J13002, J13101, J13102, } \\
\text { J13103, J13104, J13201, J13301, J13302, } \\
\text { J13303, J13304 }\end{array}$ \\
\hline Gynecological Interventions & $\begin{array}{l}\text { M00203, M00406, M00407, M00408, } \\
\text { M00503, M00504, M01205, M01206, } \\
\text { M01208, M01305, M01306, M02704, } \\
\text { M02903, M02904, M03004, M03005, } \\
\text { I01102, } 018701\end{array}$ \\
\hline Exploratory laparotomy & J12101 \\
\hline
\end{tabular}

\section{Results}

\section{The volume of the hospitals activity}

\section{a) the number of cases receiving surgical interventions}

In the 2008-2018-time interval, about 4.834.762 surgical interventions that could be performed either by MIS, or by open surgery were recorded, with an average of 439.523 surgical interventions/year, respectively 47.818 MIS and 391.705 open surgery interventions per year. There is an evident growing trend in 
the total number of procedures in the period 2008-2018; thus, the number of MIS procedures almost doubled (from 35.514 in 2008 to 66.573 MIS procedures in 2018) while for the open surgery procedures, an increase of the number of cases $42 \%$ was noted only for the last two years of the studied period (Fig. I).

\section{- evolution of the number of cases with MIS interventions}

Analyzing in detail the evolution of the number of MIS (laparoscopic and thoracoscopic) interventions, we can identify a slight trend of linear growth, with about 2849 MIS procedures per year, so that, their number at the end of the studied period (2018) was almost double, as mentioned above. The same similar trend of slight linear increase was found for the rate of MIS in total surgical cases, during 2008-2016; then-after the share remained somewhat constant (about 10-11\% of the total) for the last two years of the studied period, due to a higher increase of the number of open surgery procedures in the years 2017-2018 (Fig. 2).

By type of pathology, the analysis of MIS trend highlights a significant increase for

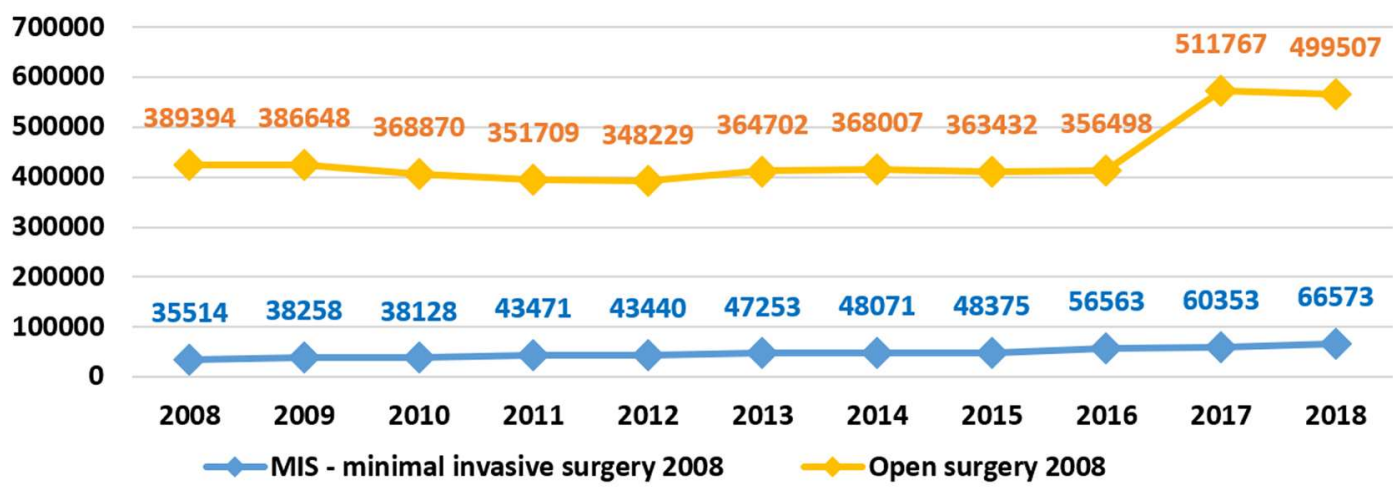

Source of data: DRG national database, NSPHMPDHB

Figure 1. Evolution of the number of cases with surgical intervention, Romania, period 2008-2018

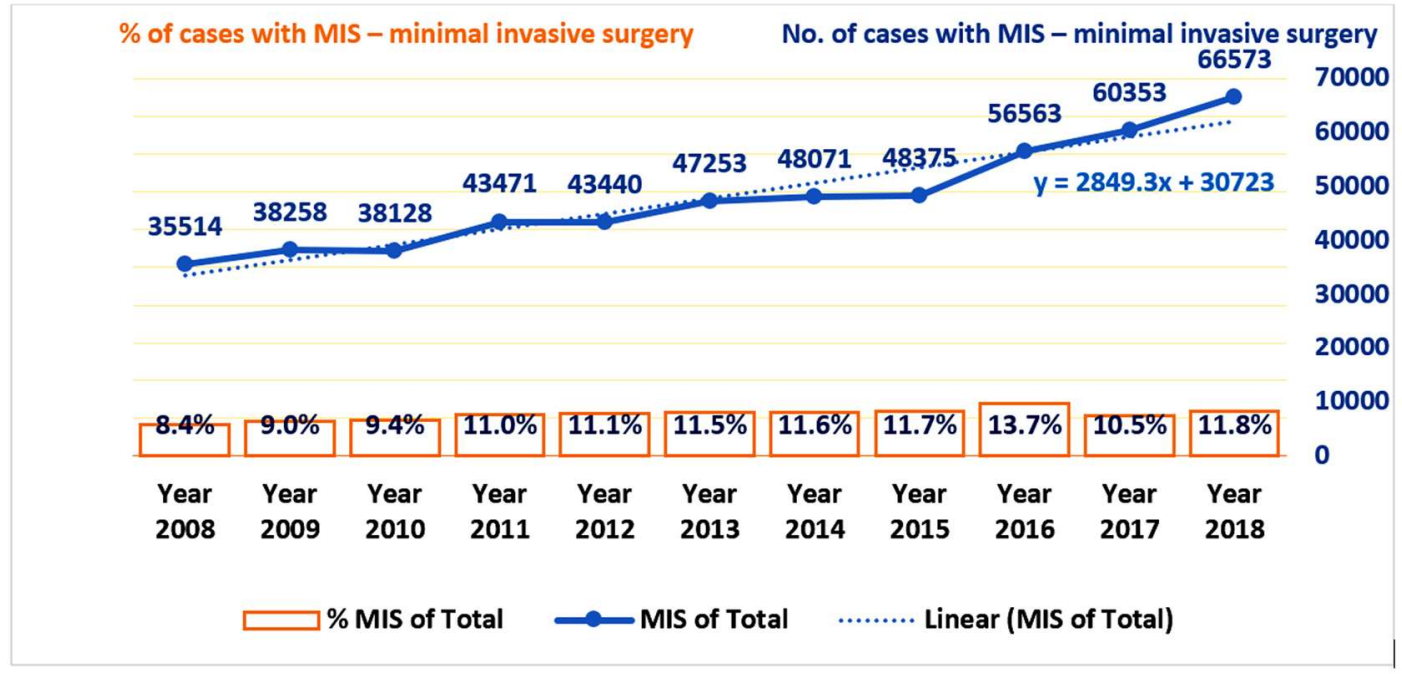

Source of data: DRG national database, NSPHMPDHB

Figure 2. Evolution of the number of cases with MIS - minimal invasive surgery, Romania, 2008-2018 


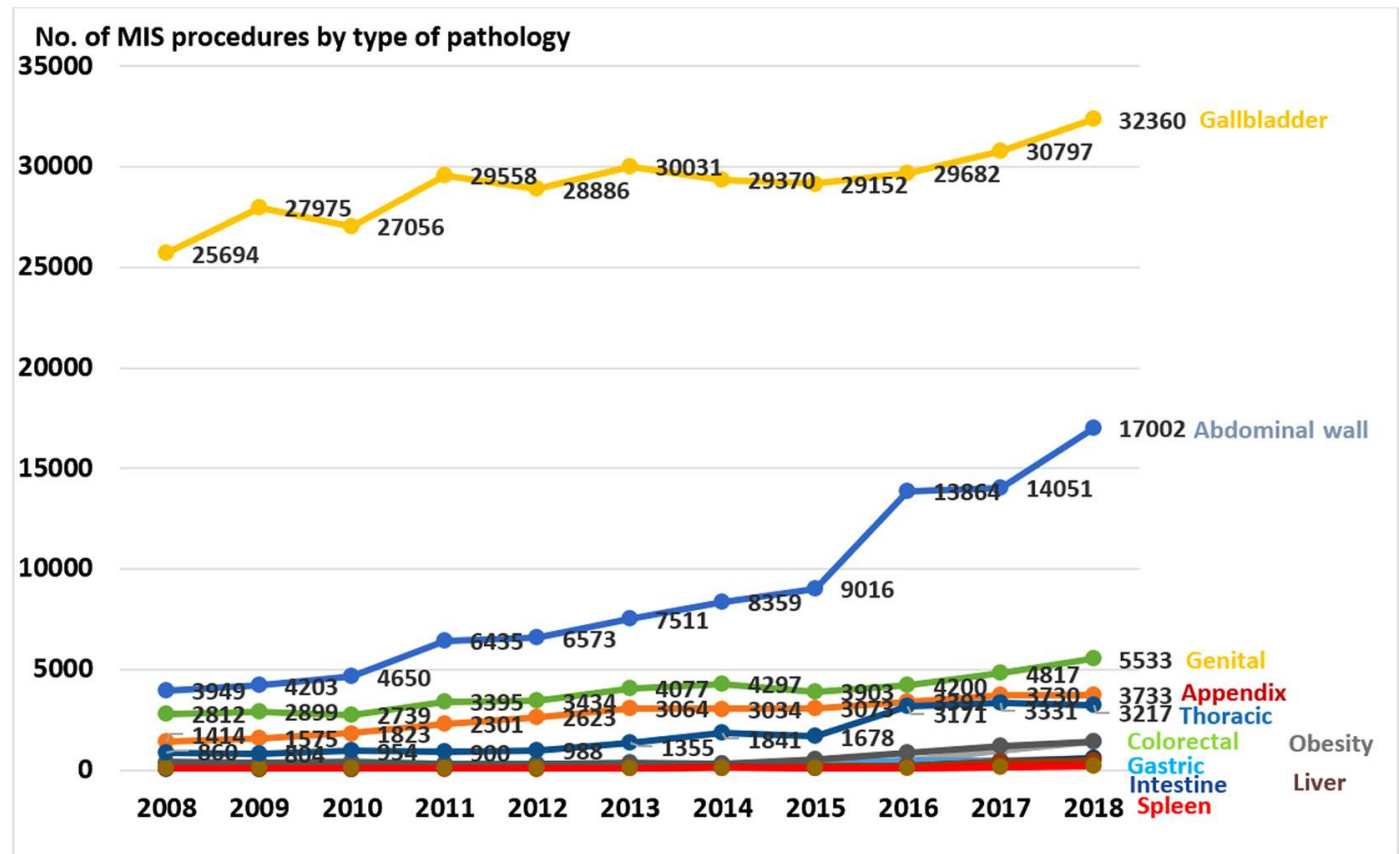

Figure 3. Average Length Of Stay (ALOS), MIS vs Open surgery, Romania, 2008-2018

almost all types of pathologies; most MIS procedures were recorded for the following pathologies: Gallbladder, Abdominal wall (eventration, hernia, laparotomy) and Genital diseases (malign and benign cancer) (Fig. 3).

\section{- correlation between the number of MIS and} open surgery interventions

The two types of surgery (MIS and open surgery) are closely correlated; for the period 2008-2016, the calculated Pearson correlation coefficient shows a strong and indirect and negative correlation $(r=-0.6 ; 95 \% \mathrm{CI})$ which denotes the number of MIS procedures increased while the number of open surgery interventions decreased. This evidence could be interpreted as a preference in the increasingly use of MIS to the detriment of open surgery techniques.

\section{b) the number of hospitalization days}

The time spent in hospital was significantly different for the two categories of hospitalizations (MIS versus open surgery interventions). Thus, the episodes of MIS hospitalization summarized about 3.064.065 hospitalization days, respectively an average length of stay (ALOS) of 5.82 days/episodes, while the hospital episodes with open surgery procedures encountered 32.994.839 hospitalization days (10 times more) which represents an average length of stay (ALOS) of 7.66 days/episodes (about 2 days longer).

\section{The Burden of MIS versus Open Surgery Interventions}

\section{a) ALOS of episodes MIS versus open surgery interventions}

In the period 2008-2018, the ALOS trend was decreasing with different rates, for the two both types of surgery (Fig. $\phi$, being two times faster for the MIS procedures (with 0.085 days/year) as compared to the open surgery interventions (with 0.04 days/year). In this respect, for the studied period, the average length of hospitalization has decreased from 7.91 days (in the year 2008) to 7.54 days (in the year 2018) for open surgery interventions, respectively from 6.29 days (in the year 2008) to 5.49 days (in the year 2018) for the hospitali- 


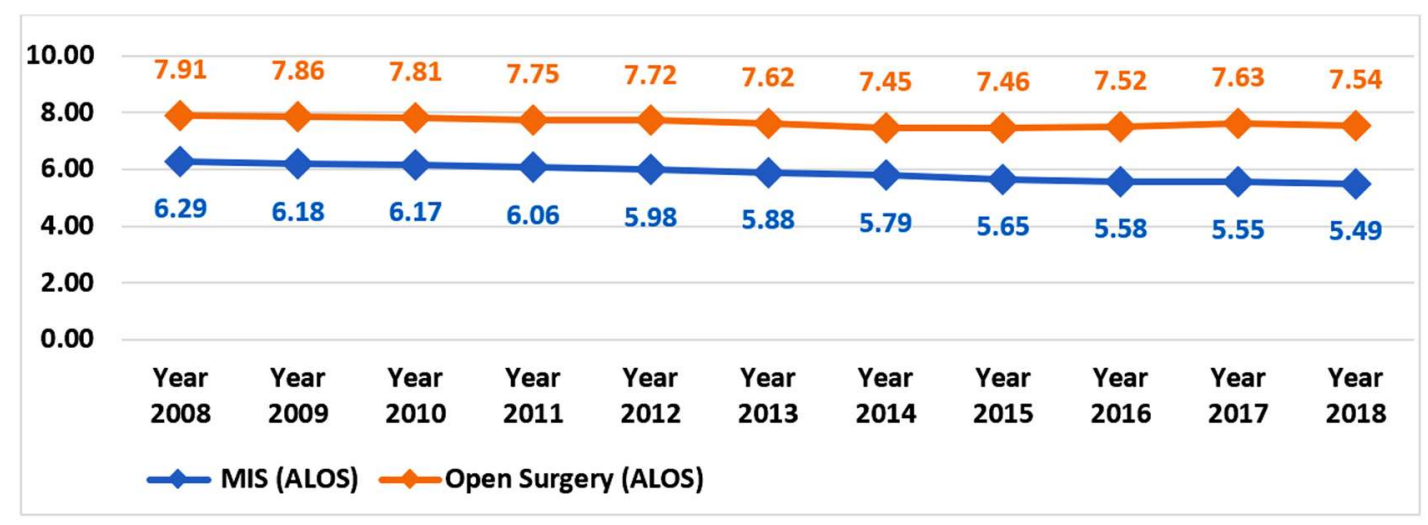

Source of data: DRG national database, NSPHMPDHB

Figure 4. Average Length Of Stay (ALOS), MIS vs Open surgery, Romania, 2008-2018

zation episodes with MIS. All these differences were statistically significant ( $t$-test; $p<0,05$ ).

The two linear trends (ALOS for MIS and ALOS for open surgery interventions) are strongly correlated $(r=0.86 ; 95 \% \mathrm{CI})$ and reveal that the difference between the two values increased year by year, from 1.6 days (in 2008) to 2.06 days (in 2018).

b) ALOS of episodes with MIS by type of pathology, year 2018

The benefits of reducing the hospital stay after MIS procedures are highly related to the type of pathology approached. In our analysis of the hospitalized MIS interventions in 2018, the lowest values of average length of stays were recorded for hernia surgery (3.95 days), obesity surgery (4.21 days) and surgery for benign gynecological pathology (4.27 days), while the best benefit (as difference between ALOS for open surgery versus MIS approach) was recorded for gallbladder surgery (7.95 days), gastric surgery (5.64 days) and incisional hernia surgery (4.33 days) (Fig. 5). For colon and rectum surgery, the difference between the two types of surgical approach was favoring laparoscopy in 2018 but, with less than one day of ALOS. The only exception to this ALOS difference favoring MIS is the video-assisted approach for thoracic pathology. Further detailed analysis is needed to explain this result. c) Evolution of the reimbursement for a case with MIS vs open surgery intervention; *tariff per weighted case (TCP) in RON/case

In economic terms, the financial burden of the surgical approach was estimated by the average tariff per weighted case (TCP) expressed by the amount of money (RON/case) reimbursed for the hospitalization episode with MIS versus the hospitalization episode with open surgery intervention. During the analyzed period, the value of the TCP increased, on average, by $12 \mathrm{RON} /$ year, while each episode of open and MIS intervention was reimbursed additionally by 101 Ron (for MIS), and by 104 RON (for open surgery interventions) respectively (Fig. 6). One can therefore observe a slightly increasing trend of the reimbursed values for MIS and open surgery procedures (in the same direction; $r=$ $0.9 ; 95 \% \mathrm{CI})$, and these values are correlated directly proportional $(\mathrm{r}=0.87 ; 95 \% \mathrm{CI})$ with to the values of the TCP annually increase. Therefore, it can be appreciated that the increasing trend of the use of MIS to the detriment of open surgery interventions did not have a pecuniary motivation.

\section{Discussions}

Nowadays, minimally invasive surgery is increasingly used proving its benefits as an alternative approach for the patients needing 


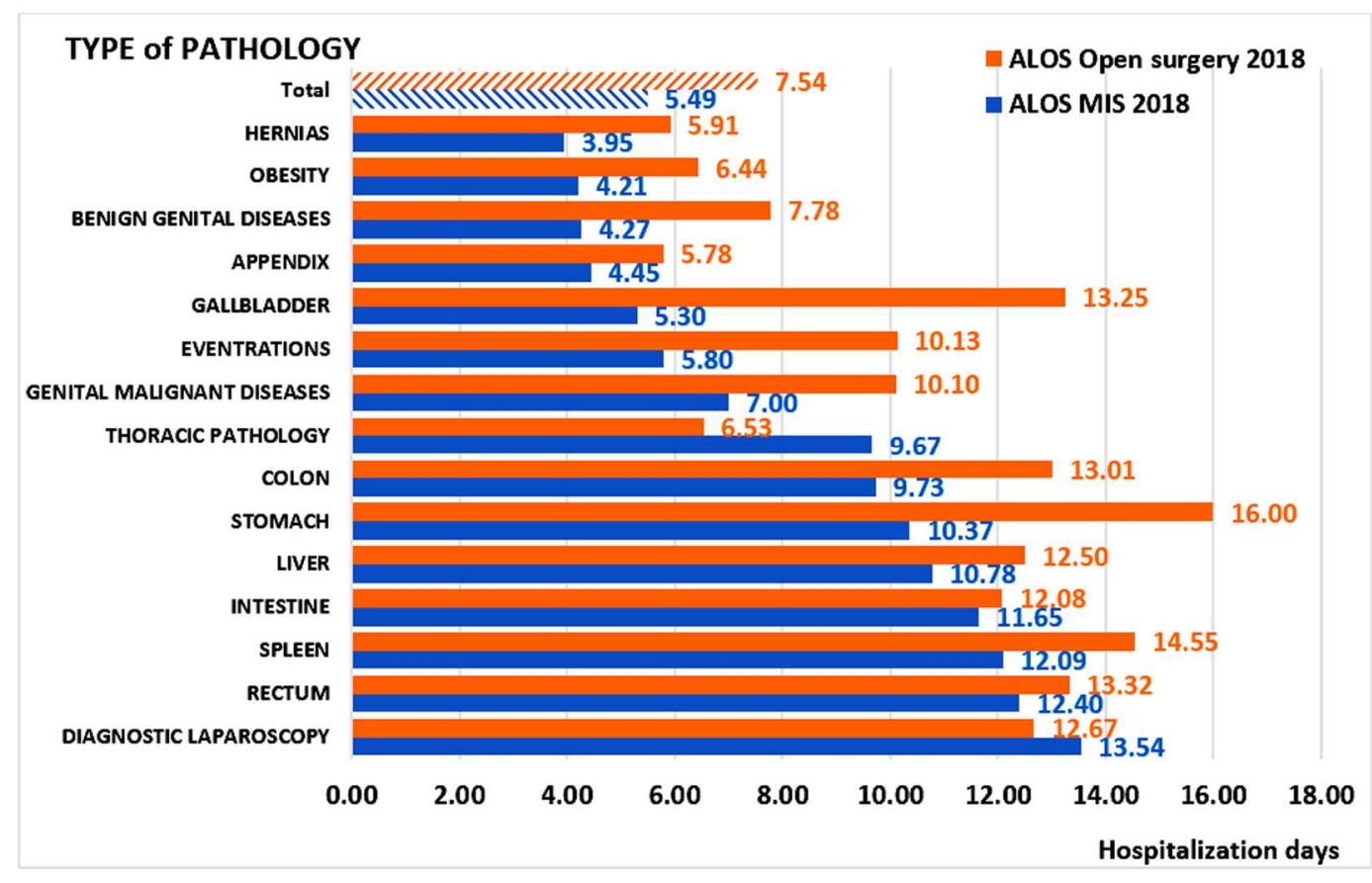

Figure 5. ALOS by type of pathology and type of surgical intervention, Romania, year 2018

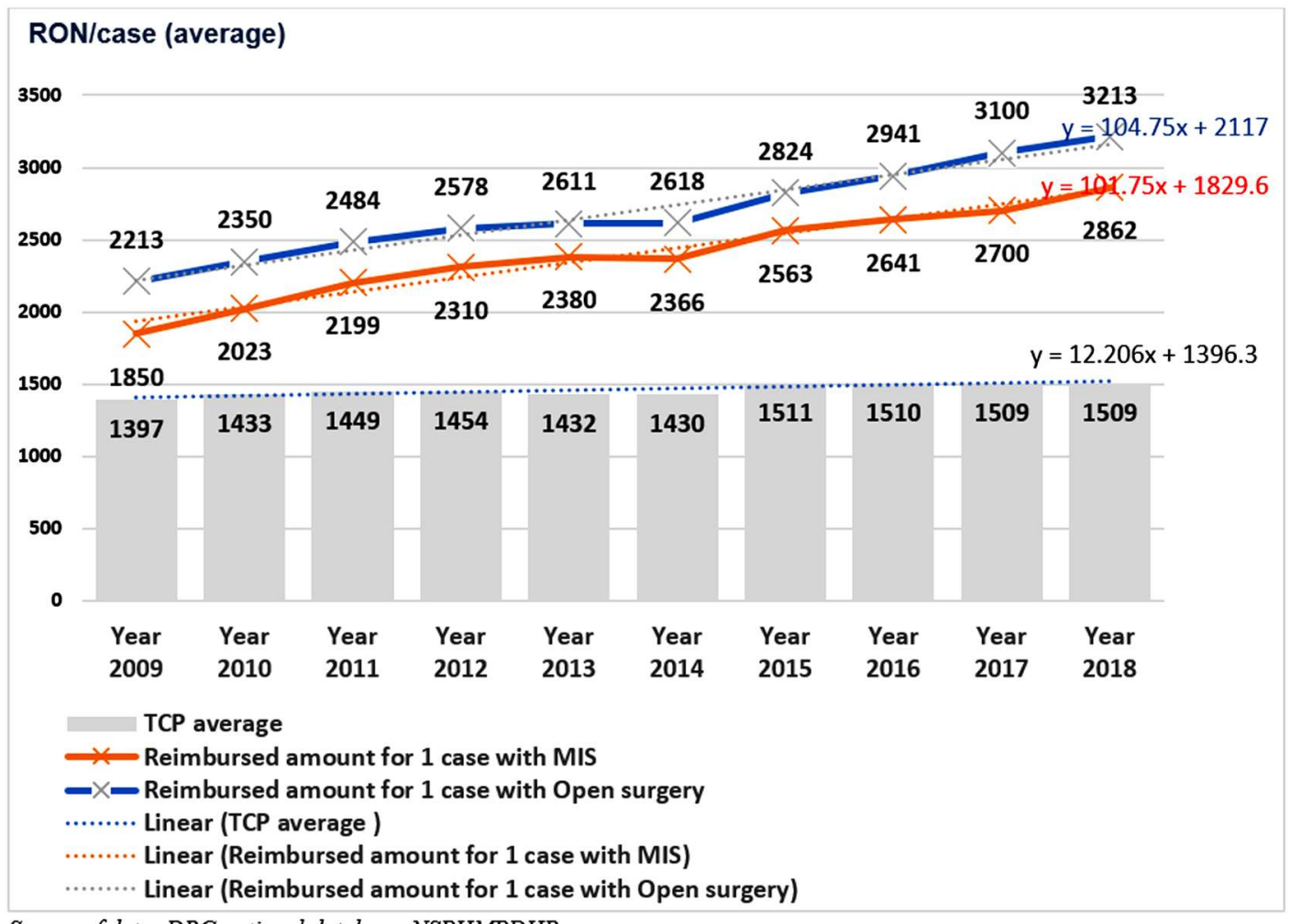

Source of data: DRG national database, NSPHMPDHB

Figure 6. Evolution of the average TCP* and the average SUM for a case with MIS versus Open surgery; *tariff per weighted case (TCP) - Ron/case 
elective surgery, including less postoperative pain, fewer early and late complications, shortened hospital stay, faster recovery times, less stress on the immune system, smaller incision, and for some procedures overall reduced therapeutic costs $(5,11)$. In emergency cases of abdominal trauma, the therapeutic laparoscopy leads to improved care in hemodynamically stable patients and this condition can be effectively and safely managed by MIS by experienced surgeons, carrying the same benefits above mentioned (11). Moreover, the evident technical advantages of laparoscopy for many operations (i.e. cholecystectomy, gastric fundoplication for GERD, or adrenalectomy), made rapidly the MIS procedure a gold standard before being proven as a superior technique over the open surgery in randomized controlled trials (12-14).

The actual technological advancements in imaging, instrumentation, cameras, and robotics are supporting MIS to have a more expensive application and, demonstrating medical and financial advantages for most of the surgical cases (15).

Same benefits and evolution were widely expected for the surgical cases in Romania but, the poor public investment in the specific technology (equipment, instruments, and training) limited its application before 2007. The members of the Romanian Association for Endoscopic Surgery (ARCE) pioneering laparoscopy in Romania and highly interested to the development of MIS in our country noticed its limited use contrary to the MIS proven advantages (7). The ARCE investigational study aiming to explore the use of laparoscopy in Romania, run in 2006, and included one-year data from 42 general surgery departments where MIS was already introduced and currently used. To be noted that the most Romanian general surgery departments (over 600) were not offering laparoscopic surgery to their patients by 2007 . The ARCE study encountered 21277 laparoscopic surgery procedures, representing $19.8 \%$ $(1 \%-42 \%)$ of the total surgical procedures, and the majority were laparoscopic cholecystectomy and appendectomy (7). This was significantly lower to the MIS application rate in EU (50-70\%) by 2007. Moreover, the ARCE study noticed that, the existing laparoscopic equipment was older than 5 years in $71 \%$ and older than 10 years in $33 \%$ of the investigated hospitals (7).

The results of the ARCE study supported the initiation and financing of argued for the National Program for Developing Laparoscopic Surgery in Romania, initiated, and supported by the Romanian Minister of Health Heath, in 2007. The program ended in 2010 and it was comprising including the purchase of 60 new technologically updated sets of laparoscopic equipment, including upgrades upgraded for advanced MIS and ended in $2010(7,8)$. As consequence, starting with 2008 MIS development was facilitated in Romania and this is why our study considered 2008 as reference.

The introduction of DRG mechanism in Romania was also a cornerstone for the accurate analyze of the health care system evolution in Romania (10).

The present study aimed to analyze the use of MIS and open surgery in Romania between 2008 and 2018, to compare their trends for the studied interval and their specific impact on the hospitalization. As available scientific evidence on medical practice regarding the use and outcomes of MIS in Romania is scarce, the information provided by the present study may be useful for the health care decisionmaking process.

In Romania, for the surgical pathology that could be solved either by MIS, or by open surgery interventions, the pattern of use for the two types of surgical approaches has changed in the studied time-interval (20082018); the number of MIS interventions doubled while the number of open surgery procedures did not follow the same growth rate. Every year, the number of MIS procedures increases by an average of only 2849 interventions, remaining at a very low rate (about 10\%) of the total yearly performed surgeries (Fig. 3). The peak of MIS use in Romania was in 2016, (reaching 13\%) but this percentage is still very low as compared with the $50-80 \%$ encountered in the Western 
European countries (16). Therefore, the study reveals that in Romania most of the surgeries that can benefit on MIS are still performed by open surgery. Moreover, the present study shows a significant increase of open surgery within the last two years of the study (20172018) (Fig. 1). This may have several explanations: 1) The significant progress of the imaging technologies and endoscopic techniques, extensively used in public and private clinics in Romania, improved the diagnostic for surgical cases which may be referred for curative surgical therapy. The increased number of patients requiring surgery, found the Romanian surgical departments not yet prepared to use MIS for complex and oncological cases, facing shortage of specific equipment and lacking of surgical training. Thus, an open surgery procedure was performed for these additional cases. To give an example, the colorectal cancer (CRC) incidence is increasing in Romania (17) while the use of MIS for CRC is less than 7\%, far behind the rate in US (40-60\%) (18) or in UK (38-76\%) (19), meaning that most of the CRC patients undergo open-surgery interventions; 2) The National Program for Developing Laparoscopic Surgery in Romania, initiated, in 2007 and supported discontinued until in 2010 by the Romanian Minister of Heath, in 2007 discontinued in 2010 and the public hospitals were not able to cover the costs of the upgraded MIS technologies required for complex surgical cases; 3) As our study clearly stated, there were not financial incentives specifically addressed to stimulate the use of MIS for the surgical cases; 4) A significant number of the patients undergoing MIS surgery in the fasting developing Romanian private hospitals are not DRG reported. This missing data may also contribute to the increased gap between the MIS and open surgery procedures in the last 2 years of the study.

Another important aspect of our study is related to the evolution of the ALOS with in the period 2008-2018 time-interval. The ALOS for MIS procedures decreased annually at a faster rate as compared to ALOS for open surgery interventions. This fact leads to a widening of the gap between the two types of surgery in terms of ALOS, the difference increasing from 1.6 days (in 2008) to 2.06 days (in 2018) in favour of MIS procedures.

The shortening of ALOS by the MIS use has been identified for various pathologies, and the best benefit was obtained for MIS interventions for Gallbladder (by 7.95 days), Gastric Surgery (by 5.64 days) and Incisional Hernia Repair (Eventrations) (by 4.33 days). The only exceptions to this pattern were ware the use of the video-assisted techniques for the thoracic pathology (VATS) and the exploratory laparoscopy. The longer hospital stays for these cases may be explained by the application of the MIS for the incurable surgical cases for which providing minimal access palliation is the only available safe option. Nowadays, the preoperative investigations support a more accurate diagnostic and open surgery will not be considered for palliation.

If we correlate this evidence of reducing the ALOS with the finding of the increasing use of MIS to the detriment of open surgery interventions, we can appreciate and estimate a net gain in terms of number of hospitalization days for the next years. If we keep and stimulate this pattern of MIS use, then significant savings to the Health Care Budget may be encountered.

However, the reduction of reducing the length of stay in the case of MIS versus open surgery interventions can be an effective and efficient measure if there is the necessary equipment and adequate use of resources. In this regard, there is a need for in-depth evidence on the effectiveness and efficiency of various MIS interventions, which must be to be supplemented by evidence on the proper use of the necessary resources, specific to each pathology.

This evidence could support for directing the resources for a more frequent use of MIS interventions for selected pathologies that prove their effectiveness and efficiency. As one of the results of the hospital activity is the time spent in the hospital, the decisions can also consider the benefits/gains obtained in 
shortening the hospitalization days for proven efficient MIS procedures.

On the other hand, the level of reimbursement for the MIS versus open surgery interventions did not changed over the analyzed period. This evidence explains the pattern of MIS interventions usage in this period while no financial incentives were introduced.

To our knowledge, the present study is the first one exploring use of MIS and open surgery in Romania on such a large scale of time and number of patients. The scientific evidence empowered by this study may be useful for the health care decision-making process, by supporting the rational decision to focus more to MIS use in Romania. However, calls for in-depth analysis to focus on the study of other factors belonging rather to specific pathology, technology or medical practice (experience in using MIS, endowment, safety, efficacy, the particularities of the surgical approach area etc.) are urgently required.

The study has some limitations as the information is related to the data registered in the DRG database. As mentioned above, an unknown number of the patients undergoing MIS or open surgery in the fasting developing Romanian private hospitals are not DRG reported and are missing for the NSPHMPDHB National Data Base. A more extensive data collection or a Romanian MIS Registry might offer a solution for the missing information.

Further research is necessary to obtain more information about the time evolutive trend of the MIS and open-surgery for organ specific pathologies.

\section{Conclusions}

MIS procedures are increasing in Romania but the rate of using it for the surgical cases is still very low.

MIS is significantly reducing the ALOS in Romania with a potential positive influence on the national healthcare budget. However, the pattern of use for MIS interventions is not financial incentives based and, calls for in-depth analysis are urgently required to identify proper instruments to stimulate the MIS use in Romania.

\section{Conflict of Interests}

Authors declare no conflict of interests.

\section{References}

1. Vecchio R, MacFayden BV, Palazzo F. History of laparoscopic surgery. Panminerva Med. 2000;42(1):87-90.

2. Kelley WE Jr. The evolution of laparoscopy and the revolution in surgery in the decade of the 1990s. JSLS : Journal of the Society of Laparoendoscopic Surgeons. 2008;12(4):351-357.

3. Buia A, Stockhausen F, Hanisch E. Laparoscopic surgery: A qualified systematic review. World journal of methodology. 2015;5(4):238-254.

4. Ochsner JL. Minimally invasive surgical procedures. The Ochsner journal, 2000;2(3):135-136

5. Mohiuddin K, Swanson SJ. Maximizing the benefit of minimally invasive surgery. J Surg Oncol. 2013:108(5):315-9.

6. Dragomirescu C, Copaescu C. History of laparoscopic surgery in Romania. Papers published in Chirurgia journal). Chirurgia (Bucur). 2010;105(5): 603-24

7. Copaescu C, A.E.N. Programul National de Dezvoltare a Chirurgie Laparoscopica in Romania 2007-2010. https://www.arce.ro/programul-dedezvoltare-a-chirurgiei-laparoscopice-in-romania/, 2007.

8. Nicolaescu E. Starea sistemului sanitar dupa trei ani de reforma. 2008, Ministerul Sanatatii: http://old.ms.ro/index.php/afis/upload/lucru.html? pag $=62 \& i d=6522 \& p g=1$

9. Radu CP, Chiriac DN, Vladescu C. Changing patient classification system for hospital reimbursement in Romania. Croatian medical journal. 2010; 51(3):250-258.

10. Vladescu C, Scintee SG. A health system focused on citizen's needs Romania. Financing, organization and drug policy. Solutions(II). Revista Romana de Bioetica. 2010;8(3):109-115.

11. Chakravartty S, Sarma DR, Noor M, Panagiotopoulos S, Patel AG. Laparoscopy has a therapeutic role in the management of abdominal trauma: A matched-pair analysis. Int J Surg. 2017;44:21-25.

12. Nilsson $G$, Larsson $S$, Johnsson F. Randomized clinical trial of laparoscopic versus open fundoplication: blind evaluation of recovery and discharge period. Br J Surg. 2000;87(7):873-8.

13. Neugebauer E, Troidl H, Spangenberger W, Dietrich A, Lefering R. Conventional versus laparoscopic cholecystectomy and the randomized controlled trial. Cholecystectomy Study Group. Br J Surg. 1991;78(2):150-4.

14. Tiberio GA, Baiocchi GL, Arru L, Agabiti Rosei C, De Ponti S, Matheis A, et al. Prospective randomized comparison of laparoscopic versus open adrenalectomy for sporadic pheochromocytoma. Surg Endosc. 2008;22(6): 1435-9.

15. Tonutti M, Elson DS, Yang GZ, Darzi AW, Sodergren MH. The role of technology in minimally invasive surgery: state of the art, recent developments and future directions. Postgrad Med J. 2017:93(1097):159-167.

16. Eurostat. Surgical Procedures and Statistics in Europe. September 2020.

17. Ionescu EM, Tieranu CG, Maftei D, Grivei A, Olteanu AO, Arbanas T, et al. Colorectal Cancer Trends of 2018 in Romania —an Important Geographical Variation Between Northern and Southern Lands and High Mortality Versus European Averages. 2021;52(1):222-228.

18. Marks, J.H. Laparoscopic TME. 2018 (cited 2020; Available from: https://www.sages.org/video/laparoscopic-tme-2/).

19. 2019 Annual Report - National Bowel Cancer Report for England and Wales 2020; Available from: https://www.nboca.org.uk/content/uploads/2020/ 01/NBOCA-2019-V2.0.pdf. 
Supplementary Table 1A. List of dedicated codes for MIS - minimal invasive surgery

(thoracic and abdominal surgical procedures with laparoscopy)

\begin{tabular}{|c|c|}
\hline Code & Name of surgical procedure \\
\hline G03003 & Endoscopic division of pleural adhesions \\
\hline G04001 & Thoracoscopy \\
\hline G04002 & Mediastinoscopy \\
\hline H04403 & Thoracoscopic drainage of pericardium \\
\hline H04601 & Thoracoscopic biopsy of pericardium \\
\hline 101101 & $\begin{array}{l}\text { Radical excision of pelvic lymph nodes via laparoscopy for gynaecological } \\
\text { malignancy }\end{array}$ \\
\hline 101103 & $\begin{array}{l}\text { Laparoscopic pelvic or abdominal lymph node sampling for staging of } \\
\text { gynaecological malignancy }\end{array}$ \\
\hline 101105 & $\begin{array}{l}\text { Laparoscopic para-aortic lymph node sampling for staging of } \\
\text { gynaecological malignancy }\end{array}$ \\
\hline 101603 & Laparoscopic splenectomy \\
\hline $\mathrm{J} 03601$ & Fundoplasty, laparoscopic approach \\
\hline J03602 & Fundoplasty, laparoscopic approach, with closure of diaphragmatic hiatus \\
\hline $\mathrm{J} 07002$ & Laparoscopic appendicectomy \\
\hline $\mathrm{J} 10102$ & Laparoscopic cholecystectomy \\
\hline $\mathrm{J} 10103$ & Laparoscopic cholecystectomy proceeding to open cholecystectomy \\
\hline $\mathrm{J} 10104$ & $\begin{array}{l}\text { Laparoscopic cholecystectomy with removal of common bile duct } \\
\text { calculus via cystic duct }\end{array}$ \\
\hline J10105 & $\begin{array}{l}\text { Laparoscopic cholecystectomy with removal of common bile duct } \\
\text { calculus via laparoscopic choledochotomy }\end{array}$ \\
\hline $\mathrm{J} 12001$ & Laparoscopy \\
\hline $\mathrm{J} 12101$ & Exploratory laparotomy \\
\hline J12601 & Laparoscopic repair of inguinal hernia, unilateral \\
\hline $\mathrm{J} 12602$ & Laparoscopic repair of inguinal hernia, bilateral \\
\hline J12701 & Laparoscopic repair of femoral hernia, unilateral \\
\hline
\end{tabular}

\begin{tabular}{|c|c|}
\hline Code & Name of surgical procedure \\
\hline $\mathrm{J} 12702$ & Laparoscopic repair of femoral hernia, bilateral \\
\hline M00201 & Laparoscopic rupture of ovarian cyst or abscess \\
\hline M00501 & Laparoscopic ovarian cystectomy, unilateral \\
\hline M00502 & Laparoscopic ovarian cystectomy, bilateral \\
\hline M01001 & Laparoscopic salpingotomy \\
\hline M01002 & Laparoscopic salpingolysis \\
\hline M01201 & Laparoscopic partial salpingectomy, unilateral \\
\hline M01202 & Laparoscopic partial salpingectomy, bilateral \\
\hline M01203 & Laparoscopic salpingectomy, unilateral \\
\hline M01204 & Laparoscopic salpingectomy, bilateral \\
\hline M01301 & Laparoscopic salpingo-oophorectomy, unilateral \\
\hline M01302 & Laparoscopic salpingo-oophorectomy, bilateral \\
\hline M01303 & $\begin{array}{l}\text { Laparoscopically assisted unilateral Oophorectomy with bilateral } \\
\text { salpingo-oophorectomy }\end{array}$ \\
\hline M02703 & Uterine myomectomy via laparoscopy \\
\hline M03007 & $\begin{array}{l}\text { Laparoscopically assisted vaginal hysterectomy with unilateral } \\
\text { salpingo-0ophorectomy }\end{array}$ \\
\hline M03008 & $\begin{array}{l}\text { Laparoscopically assisted vaginal hysterectomy with bilateral } \\
\text { salpingo-oophorectomy }\end{array}$ \\
\hline M03010 & $\begin{array}{l}\text { Laparoscopically assisted vaginal hysterectomy converted in abdominal } \\
\text { hysterectomy with unilateral salpingo-oophorectomy }\end{array}$ \\
\hline M03011 & $\begin{array}{l}\text { Laparoscopically assisted vaginal hysterectomy converted in abdominal } \\
\text { hysterectomy with bilateral salpingo-oophorectomy }\end{array}$ \\
\hline M03204 & Other laparoscopic repair of uterus \\
\hline M03301 & Laparoscopic reconstruction of uterus and supporting structures \\
\hline M06002 & Laparoscopic excision of lesion of pelvic cavity \\
\hline
\end{tabular}

Supplementary Table 1B. List of surgical open surgery procedures. For the abdominal pathology laparoscopy (code J12001) was added when it was performed laparoscopically

\begin{tabular}{ll}
\hline Code & Name of the surgical procedure \\
\hline B02001 & Other procedures on thymus \\
\hline G02802 & Other procedures on bronchus \\
\hline G03001 & Incision of pleura \\
\hline G03103 & Division of pleural adhesions \\
\hline G03104 & Biopsy of pleura \\
\hline G03202 & Wedge resection of lung \\
\hline G03203 & Radical wedge resection of lung \\
\hline G03204 & Endoscopic wedge resection of lung \\
\hline G03205 & Lung volume reduction surgery \\
\hline G03301 & Lobectomy of lung \\
\hline G03302 & Radical lobectomy \\
\hline G03401 & Pneumonectomy \\
\hline G03403 & Radical pneumonectomy \\
\hline G03501 & Endoscopic pulmonary decortication \\
\hline G03502 & Pulmonary decortication \\
\hline G03503 & Pleurectomy \\
\hline G03701 & Pleurodesis \\
\hline G03702 & Endoscopic pleurodesis \\
\hline G03703 & Other repair of lung or pleura \\
\hline G03901 & Other procedures on lung and pleura, intrathoracic approach \\
\hline G04801 & Other procedures on chest wall, mediastinum or diaphragm, \\
\hline intrathoracic approach \\
\hline O04803 & Other procedures on chest wall \\
\hline
\end{tabular}

\begin{tabular}{|c|c|}
\hline Code & Name of the surgical procedure \\
\hline $\mathrm{H} 04404$ & Subxyphoid drainage of pericardium \\
\hline 100601 & Biopsy of lymph node \\
\hline 101102 & Radical excision of pelvic lymph nodes for gynaecological malignancy \\
\hline 01601 & Partial splenectomy \\
\hline 01602 & Splenectomy \\
\hline 101701 & Splenorrhaphy \\
\hline J02201 & Gastrotomy \\
\hline J02601 & Partial distal gastrectomy with gastroduodenal anastomosis \\
\hline $\mathrm{J} 02602$ & Partial distal gastrectomy with gastrojejunal anastomosis \\
\hline $\mathrm{J} 02603$ & Partial proximal gastrectomy with oesophagogastric anastomosis \\
\hline $\bar{J} 02701$ & $\begin{array}{l}\text { Partial gastrectomy with gastroduodenal anastomosis following previous } \\
\text { procedure for peptic ulcer disease }\end{array}$ \\
\hline J02702 & $\begin{array}{l}\text { Partial gastrectomy with gastrojejunal anastomosis following previous } \\
\text { procedure for peptic ulcer disease }\end{array}$ \\
\hline J02703 & $\begin{array}{l}\text { Partial gastrectomy with Roux-en-Y reconstruction following previous } \\
\text { procedure for peptic ulcer disease }\end{array}$ \\
\hline J02801 & $\begin{array}{l}\text { Selective vagotomy with partial gastrectomy and gastroduodenal } \\
\text { anastomosis }\end{array}$ \\
\hline J02802 & Selective vagotomy with partial gastrectomy and gastrojejunal anastomosis \\
\hline J03001 & Total gastrectomy \\
\hline J03002 & Subtotal gastrectomy \\
\hline $\mathrm{J} 03003$ & Radical gastrectomy \\
\hline J03103 & Local excision of gastric lesion \\
\hline J03201 & Gastrostomy \\
\hline $\mathrm{J} 03202$ & Gastro-enterostomy \\
\hline
\end{tabular}




\begin{tabular}{|c|c|}
\hline Code & Name of the surgical procedure \\
\hline J03704 & Other repair of stomach \\
\hline J03902 & Gastric reduction \\
\hline J03903 & Gastric bypass \\
\hline $\mathbf{J} 03904$ & Surgical reversal of procedure for morbid obesity \\
\hline $\mathrm{J} 03905$ & Insertion of gastric bubble (balloon) \\
\hline $\mathrm{J} 04001$ & Other procedures on stomach \\
\hline J04501 & Resection of small intestine with formation of stoma \\
\hline J04502 & Resection of small intestine with anastomosis \\
\hline J04601 & Biopsy of small intestine \\
\hline $\mathrm{J} 04604$ & Excision of other lesions of small intestine \\
\hline J04801 & Reduction of intussusception of small intestine \\
\hline J04802 & Reduction of volvulus of small intestine \\
\hline $\bar{J} 04902$ & Closure of ileostomy with restoration of bowel continuity, without resection \\
\hline J04903 & Closure of other stoma of small intestine \\
\hline J05001 & Repair of small intestine with single anastomosis \\
\hline $\mathrm{J} 05002$ & Repair of small intestine with multiple anastomoses \\
\hline $\bar{J} 05101$ & Other repair of small intestine \\
\hline J05106 & Closure of fistula of small intestine \\
\hline J05301 & Other procedures on small intestine \\
\hline 506201 & Limited excision of large intestine with formation of stoma \\
\hline $\mathrm{J} 06202$ & Right hemicolectomy with formation of stoma \\
\hline $\mathrm{J} 06203$ & Limited excision of large intestine with anastomosis \\
\hline $\mathrm{J} 06205$ & Sub-total colectomy with formation of stoma \\
\hline $\mathrm{J} 06210$ & Left hemicolectomy with formation of stoma \\
\hline $\mathrm{J} 06302$ & Excision of other lesion of large intestine \\
\hline$\overline{J 06402}$ & Other colostomy \\
\hline $\mathrm{J} 06403$ & Temporary colostomy \\
\hline $\bar{J} 06501$ & Reduction of intussusception of large intestine \\
\hline $\bar{J} 06502$ & Reduction of volvulus of large intestine \\
\hline $\bar{J} 06605$ & Closure of colostomy with restoration of bowel continuity \\
\hline $\mathrm{J} 06606$ & Closure of other stoma of large intestine \\
\hline $\mathrm{J} 06607$ & Restoration of bowel continuity after Hartmann's procedure \\
\hline $\mathrm{J} 06609$ & Other repair of large intestine \\
\hline $\mathrm{J} 06610$ & Closure of fistula of large intestine \\
\hline $\mathrm{J} 06801$ & Repair of exomphalos, minor \\
\hline $\mathrm{J} 06802$ & Repair of exomphalos, major \\
\hline$\overline{J 06803}$ & Creation of prosthetic pouch for exomphalos \\
\hline$\overline{\mathrm{J}} 06804$ & $\begin{array}{l}\text { Delayed primary closure of exomphalos following creation of prosthetic } \\
\text { pouch }\end{array}$ \\
\hline $\mathrm{J} 06902$ & Other procedures on large intestine \\
\hline $\mathrm{J} 07001$ & Appendicectomy \\
\hline $\mathrm{J} 07701$ & Per anal submucosal excision of rectal tumour \\
\hline J07703 & Trans-sphincteric excision of rectal tumour \\
\hline $\mathrm{J} 07710$ & Excision of other rectal lesion \\
\hline $\mathrm{J} 07801$ & Rectosigmoidectomy with formation of stoma \\
\hline$\overline{J 07805}$ & Perineal rectosigmoidectomy \\
\hline$\overline{J 07806}$ & Definitive intestinal resection and pull-through anastomosis \\
\hline $\bar{J} 07901$ & $\begin{array}{l}\text { High restorative anterior resection of rectum with intraperitoneal } \\
\text { anastomosis }\end{array}$ \\
\hline $\bar{J} 07902$ & $\begin{array}{l}\text { Low restorative anterior resection of rectum with extraperitoneal } \\
\text { anastomosis }\end{array}$ \\
\hline $\mathrm{J} 07903$ & Low restorative anterior resection of rectum with coloanal anastomosis \\
\hline$\overline{\mathrm{J} 07904}$ & $\begin{array}{l}\text { Ultra low restorative anterior resection of rectum with sutured coloanal } \\
\text { anastomosis }\end{array}$ \\
\hline $\mathrm{J} 08401$ & Abdominal rectopexy \\
\hline $\bar{J} 08601$ & Other procedures on rectum \\
\hline $\mathrm{J} 08904$ & Excision of lesion of liver \\
\hline
\end{tabular}

\begin{tabular}{|c|c|}
\hline Code & Name of the surgical procedure \\
\hline$\overline{J 08905}$ & Segmental resection of liver \\
\hline $\mathrm{J} 08906$ & Lobectomy of liver \\
\hline $\mathrm{J} 08907$ & Trisegmental resection of liver \\
\hline$\overline{J 08908}$ & Total hepatectomy \\
\hline $\mathrm{J} 09003$ & Transplantation of liver \\
\hline $\mathrm{J} 09004$ & Other repair of liver \\
\hline J09103 & Excision of hydatid cyst of liver with drainage and excision of liver tissue \\
\hline $\mathrm{J} 09203$ & Other procedures on liver \\
\hline $\mathrm{J} 10106$ & Cholecystectomy with choledochotomy \\
\hline $\mathrm{J10107}$ & $\begin{array}{l}\text { Cholecystectomy with choledochotomy and biliary intestinal anastomosis } \\
\end{array}$ \\
\hline $\mathrm{J10202}$ & Radical resection of hepatic ducts \\
\hline $\mathrm{J10203}$ & Radical resection of hepatic ducts with resection of segment of liver \\
\hline J10509 & Hepaticoenterostomy \\
\hline $\mathrm{J} 12603$ & Repair of inguinal hernia, unilateral \\
\hline $\mathrm{J} 12604$ & Repair of inguinal hernia, bilateral \\
\hline $\mathrm{J} 12703$ & Repair of femoral hernia, unilateral \\
\hline $\mathrm{J} 12704$ & Repair of femoral hernia, bilateral \\
\hline J12801 & Repair of umbilical hernia \\
\hline $\mathrm{J} 12802$ & Repair of epigastric hernia \\
\hline $\mathrm{J} 12803$ & Repair of linea alba hernia \\
\hline J12901 & Repair of incisional hernia \\
\hline J12902 & Repair of incisional hernia with muscle transposition \\
\hline $\mathrm{J} 12903$ & Repair of incisional hernia with prosthesis \\
\hline J12904 & Repair of incisional hernia with resection of strangulated intestine \\
\hline $\mathrm{J13001}$ & Repair of parastomal hernia \\
\hline $\mathrm{J} 13002$ & Repair of parastomal hernia with resiting of stoma \\
\hline J13101 & Repair of other abdominal wall hernia \\
\hline J13102 & Repair of other abdominal wall hernia with muscle transposition \\
\hline J13103 & Repair of other abdominal wall hernia with prosthesis \\
\hline J13104 & $\begin{array}{l}\text { Repair of other abdominal wall hernia with resection of strangulated } \\
\text { intestine }\end{array}$ \\
\hline $\mathrm{J} 13201$ & Repair of incarcerated, obstructed or strangulated hernia \\
\hline $\mathrm{J} 13301$ & Repair of traumatic diaphragmatic hernia \\
\hline J13302 & Repair of diaphragmatic hernia, abdominal approach \\
\hline $\mathrm{J13303}$ & Repair of diaphragmatic hernia, thoracic approach \\
\hline$\overline{J 13304}$ & $\begin{array}{l}\text { Repair of diaphragmatic hernia with use of body wall flap or insertion of } \\
\text { prosthetic patch }\end{array}$ \\
\hline M00203 & Rupture of ovarian cyst or abscess \\
\hline M00406 & Partial oophorectomy \\
\hline M00407 & Oophorectomy, unilateral \\
\hline M00408 & Oophorectomy, bilateral \\
\hline$\overline{M 00503}$ & $\begin{array}{l}\text { Ovarian cystectomy, unilateral } \\
\end{array}$ \\
\hline$\overline{M 00504}$ & Ovarian cystectomy, bilateral \\
\hline M01205 & Partial salpingectomy, unilateral \\
\hline M01206 & Salpingectomy, unilateral \\
\hline M01208 & Salpingectomy, bilateral \\
\hline M01305 & Salpingo-oophorectomy, bilateral \\
\hline M01306 & unilateral 0ophorectomy with bilateral salpingo-oophorectomy \\
\hline M02704 & Uterine myomectomy \\
\hline M02903 & Abdominal hysterectomy with unilateral salpingo-oophorectomy \\
\hline M02904 & Abdominal hysterectomy with bilateral salpingo-oophorectomy \\
\hline M03004 & Vaginal hysterectomy with unilateral salpingo-oophorectomy \\
\hline M03005 & Vaginal hysterectomy with bilateral salpingo-oophorectomy \\
\hline 018701 & Biopsy of soft tissue \\
\hline$\overline{S 06805}$ & Nonincisional drainage of respiratory tract \\
\hline
\end{tabular}

